\title{
Doses of organic substrate in the production of red chili pepper seedlings
}

\author{
Francisco Cleilson Lopes Costa ${ }^{\text {I }}$, Regimara Francisca Bernardo da Silva '; Antônia Thalyta Lopes Silveira '; \\ Keline Sousa Albuquerque Uchôa ${ }^{\text {; }}$ Maria Vanessa da Costa de Deus ${ }^{\text {; }}$ Maria Monica da Silva ${ }^{\text {I }}$
}

cllsncosta@gmail.com

1. Instituto Federal de Educação, Ciência e Tecnologia do Ceará (IFCE) - Campus Limoeiro do Norte, Rua Estevão Remigio, $n^{\circ} 1145$, Limoeiro do Norte, Brasil.

Histórico do Artigo:

Recebido: 05 de setembro de 2016

Aceito: 11 de janeiro de 2017

Publicado: 18 de julho de 2017

\begin{abstract}
Organic matter influences the plant performance, mainly on early stages of the plant development. The aim of this work was to assess manure doses influence on the germination potential of red pepper seeds. The research was carried out in greenhouse at Unidade Experimental de Pesquisa e Extensão (UEPE) of Instituto Federal do Ceará, located in Chapada do Apodi, Limoeiro do Norte - Ceará, geographic coordinates $5^{\circ} 10^{\prime}$ S, $38^{\circ} 00^{\prime}$ W, and altitude of 145,9 $\mathrm{m}$. The experimental design was completely randomized, the treatments were composed by manure (M) and soil proportions (S) (\%): 0M-100S, 25M-75S, 50M-50S, 75M-25S and 100M-0S, respectively. The variables assessed were Emergence Speed Index (ESI), Viability Rate (\%VR), Post-Emergence Rate of Abortion (\%PEA), Global Germination (\%GG), Seedling Height (SH) (cm), Root Depth (RD) (cm), Aerial Length (AL) (cm), Number of Leaves (NL), Fresh Weight (FW) (g) and Dry Weight (DW) (g).
\end{abstract}

Keywords: Capsicum baccatum, Seedlings early performance, Manure.

\section{Doses de substrato orgânico na produção de mudas de pimenta dedo de moça}

Resumo: A matéria orgânica influencia no desenvolvimento das plantas, principalmente nos estádios iniciais de seu desenvolvimento. 0 objetivo deste trabalho foi avaliar a influência de doses de esterco sobre o potencial de germinação de sementes de pimenta dedo de moça. A pesquisa foi desenvolvida em casa de vegetação na Unidade Experimental de Pesquisa e Extensão (UEPE) do Instituto Federal do Ceará, localizada na Chapada do Apodi, Limoeiro do Norte - Ceará, coordenadas $5^{\circ} 10^{\prime} \mathrm{S}, 38^{\circ} 00^{\prime} \mathrm{W}$, altitude 145,9 m. 0 delineamento experimental foi inteiramente casualizado, os tratamentos foram compostos de esterco e solo nas proporções (\%) $0 \mathrm{M}-100 \mathrm{~S}, 25 \mathrm{M}-$ 75S, 50M-50S, 75M-25S e 100M-0S. As variáveis avaliadas foram Índice de Velocidade de Emergência (ESI), Taxa de Viabilidade (\%VR), Percentagem de Aborto Pós-Emergência (\%PEA), Germinação Global (\%GG), Altura Total (SH) (cm), Profundidade Radicular (RD) (cm), Comprimento da Parte Aérea (AL) (cm), Número de Folhas (NL), Massa Fresca (FW) e Massa Seca (DW) (g).

Palavras-chave: Capsicum baccatum, Desenvolvimento inicial de mudas, Esterco. 


\section{Dosis de sustrato orgánico en la producción de plántines de pimienta roja}

Resumen: La materia orgánica influye en el desarrollo de las plantas, especialmente en las primeras etapas de su desarrollo. El objetivo de este estudio fue evaluar la influencia de estiércol en el potencial de germinación de las semillas de pimienta. La investigación se logró en un invernadero a la Unidade Experimental de Pesquisa e Extensão (UEPE) del Instituto Federal do Ceará, situado en la Chapada do Apodi, Limoeiro do Norte - Ceará, coordenadas $5^{\circ} 10$ ' $\mathrm{S}, 38^{\circ} 00^{\prime} \mathrm{W}$, altura 145,9 m. El diseño experimental fue completamente asignados al azar, los tratamientos se componen de estiércol y el suelo en las proporciones 0M-100S, 25M-75S, 50M-50S, 75M-25S y 100M-0S. Las variables analizadas fueron el Índice de Velocidad de Emergencia (ESI), la Tasa de Viabilidad (\%VR), Porcentaje Aborto Después de las Emergencias (\%PEA), Germinación Global (\%GG), Altura Total (SH) (cm) Profundidad de Raíz Parte (RD) (cm) Longitud del Aire (AL) (cm), Número de Hojas (NL), Materia Fresca (FW) y Materia Seca (DW) (g).

Palabras clave: Capsicum baccatum, Desarrollo inicial de plántines, Estiércol.

\section{INTRODUCTION}

In Brazil, 25 species of the genus Capsicum are present, but only five are grown. The others 20 species are wild or semi domesticated. The cultivated ones are Capsicum baccatum var. pendulum, C. annuum, C. chinense, C. frutescens and C. pubescens.

Red pepper is highly nutritional and has pharmacological and anti oxidizing action. In Brazil the cultivation of red pepper is carried out in short scale production, the packing and commercialization are mainly dependent on family farming. So, it denotes an opportunity to increase its cultivation given the enlarging demand by this condiment, which remains around 80 million reais per year. The consumption of red pepper goes through the entire world because of its flavor. In supermarkets, it is available as pepperoni and paprika.

Knowing the physiological maturity, determining the point of maturation, describing the phenological cycle, determining its productivity which occurs when the maximum dry matter content concurs with the highest vigor of the seed, combined with good environmental and growing conditions (temperature, humidity, irrigation, soil fertility, etc.) that are information on demand that stops the companies of expanding off pepper agribusiness in the country, beyond the labor demand.

So to know which are the best cultivation techniques for this culture and which are most suitable for each region is important to increase the cultivation of red pepper. Thus, it is a common practice to make substrates for propagation of various cultures adding corral tanned 
manure in order to enrich the soil. However, the manure tends to reduce germination. This happens because of the misbalance in the soil fertility, due to the low carbon nitrogen ratio. And it raises the carbon demand rather than the nitrogen demand, which may be harmful to the plantlets. As well as according to Mendes et al. (2006 cited by ARAUJ0, J0AQUIM \& BARJA 2012), germination and early development of the seedlings may be affected by the composition of any substrate, which must be formulated according to the requirements of the seeds in relation to its size and shape.

Among the variables to be evaluated for the production of quality seeds for establishment and to minimize their deterioration in the field, the ones that deserve more attention are the maturation point of the fruits according to Pereira et. al (2014), who observed the most suitable maturation point was at 45 days after anthesis, with a rest period of 10 days before seed withdrawal.

The organic nitrogen fertilization is utilized as an alternative for agriculture. It improves greatly the physical and biological soil conditions that in turn of the action of the soil microorganisms that provides nutrients as they are demanded in soil exchange complex. Various types of organic materials may be incremented to the soil such as castor bean, chicken litter, cattle manure, pig manure, sheep manure, vinasse, dairy industry waste etc.

Compared with manure $3.1 \%$, in terms of nitrogen $(\mathrm{N})$, vinasse has around $0.5 \%$ of $\mathrm{N}$. However, rich nitrogen materials tend to interfere with the initial development of plants. By working with vinasse application, among other products like sunflower, castor beans and peanuts, it presented interference on the index emergence speed, final emergence, first count emergence, aerial length and dry aerial biomass of sunflower and peanuts (RAMOS et al. 2008).

By working with castor bean, Oliveira et al. (2009) observed that the pH-corrected sewage sludge performed better and two soil types treated without sludge had lower root volume. Organic products industrialized have been widely used to increase the efficiency of production, the release efficiency of organic fertilizer nutrients, etc. (WAGNER JUNIOR et al. 2006).

Working with shading levels with Theobroma grandiflorum (Willd. Ex Spreng.), Smith et al. (2007) found for shading recommendation in early development, for providing better mass allocation performance to aerial, height, diameter and number of leaves. 
The aim of this paper was to assess the influence of manure doses on the potential emergence of red pepper seeds.

\section{MATERIAL AND METHODS}

The experiment conducted in a greenhouse in Unidade Experimental de Pesquisa $e$ Extensão of Instituto Federal do Ceará, Campus Limoeiro do Norte, in Chapada do Apodi, with coordinates $5^{\circ} 10^{\prime}$ latitude south, $38^{\circ} 00^{\prime}$ longitude west, and altitude of $145.9 \mathrm{~m}$. In Köppen classification, the climate is BSw'h', i.e., dry and very hot, with annual rainfall of $822.4 \mathrm{~mm}$, with two seasons: dry, which runs from June to January, and, usually, rainy season, from February to May.

The experiment was carried out in a completely randomized design (CRD), with five treatments and with 50 replications, totalizing 250 seedlings in the useful area. The treatments consisted of soil and manure mixture in the proportions (\%) Manure-Soil: 0M-100S; 25M-75S; 50M-50S; 75M-25S; and 100M-0S. Soil from a Red Cambisol and cattle manure was used to compose the substrate. The substrates were sieved, measured with a container of knownvolume in the mentioned proportions, and then mixed. So, trays for germination with capacity of 50 cells $(10 \times 5)$ were fulfilled with the substrates, and watered, so the seeds were sown with one seed per cell.

To calculate the Emergence Speed Index (ESI), suggested by Maguire (1962) at 7, 11,14 and 28 days after sowing (DAS), it was used the formula (1) in what, NES: sum of Number of Emerged Seeds from $\mathrm{i}^{\text {th }}$ to $\mathrm{n}^{\text {th }}$ day after emergence; TNST: Total Number of Seeds per Treatment. The Viability Rate (\%VR) was calculated at the end of the experiment at 28 DAS, by the formula (2). And Post-Emergence percentage of Abortion (\%PEA) was calculated by the formula (3) and Global Germination (\%GG), including dead and alive seedlings by the formula (4). Exploratory tests were performed on substrate 'soil'.

$$
\begin{aligned}
\text { (1) } \quad \mathrm{ESI} & =\sum_{\mathrm{i}=1}^{\mathrm{n}} \frac{\mathrm{NES}_{\mathrm{n}}}{\mathrm{TNST}} \\
\text { (2) } \quad \% \mathrm{VR} & =\left(\frac{\mathrm{NES}}{\mathrm{TNST}}\right) * 100
\end{aligned}
$$




$$
\begin{aligned}
& \text { (3) } \% \mathrm{PEA}=\left(\frac{\text { NEDP }}{\mathrm{TSS}}\right) * 100 \\
& \text { (4) } \% \mathrm{GG}=\left(\frac{\mathrm{NES}+\mathrm{NEDP}}{\mathrm{TNST}}\right) * 100
\end{aligned}
$$

The total height $(\mathrm{cm})$, the root depth $(\mathrm{cm})$ and the aerial length $(\mathrm{cm})$ were measured. The number of leaves was counted in addition to the measurement of the mean of fresh and dry weight (g) of six seedlings.

The data analysis was done on Assistat Statistical Assistance Software 7.7 beta edition at $5 \%$ of probability, the mean differences by Scott-Knott test, and the normality data test was done by Shapiro-Wilk test.

\section{RESULTS AND DISCUSSION}

Figure 1 shows the emergence rate of seeds for such treatments. It was found that the higher speed emergence occurred in the treatment 100M-0S with ESI $=0.786$, the lower with ESI $=0.105$ and the average speed emergence with ESI $=0.571$.

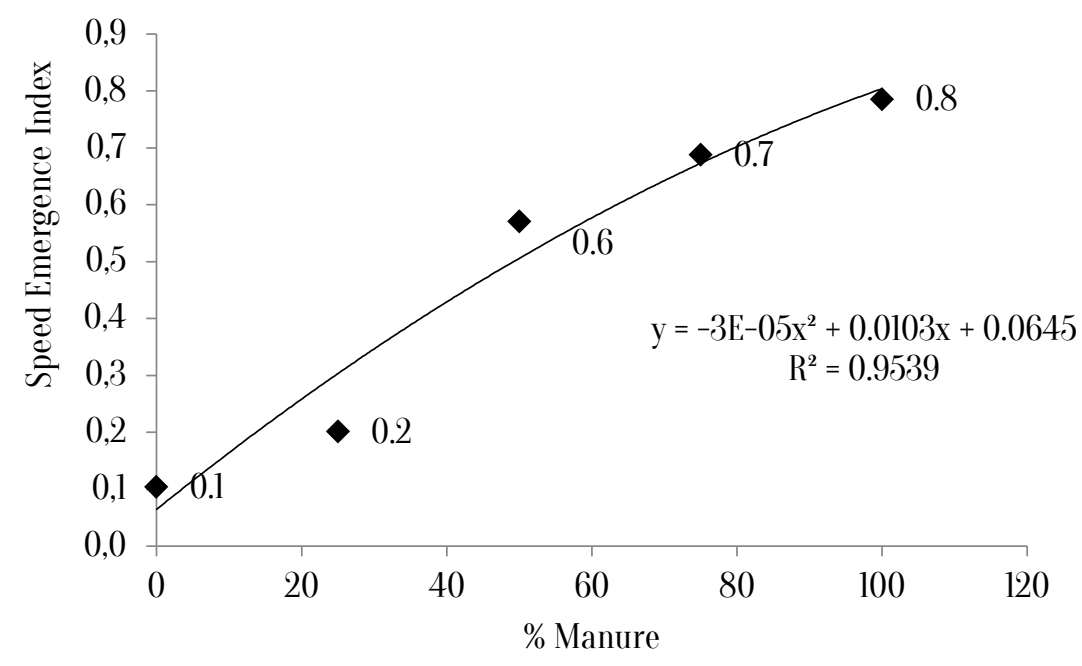

Figure 1. Emergence rate.

Source: Authors. 
Figure 2 shows the viability for seeds due treatments. It was found that the higher emergence rate $84 \%$ occurred in treatment $100 \mathrm{M}-0 \mathrm{~S}$; the lowest rate $14 \%$ in treatment $0 \mathrm{M}-100 \mathrm{~S}$, and the average germination rate was $62 \%$.

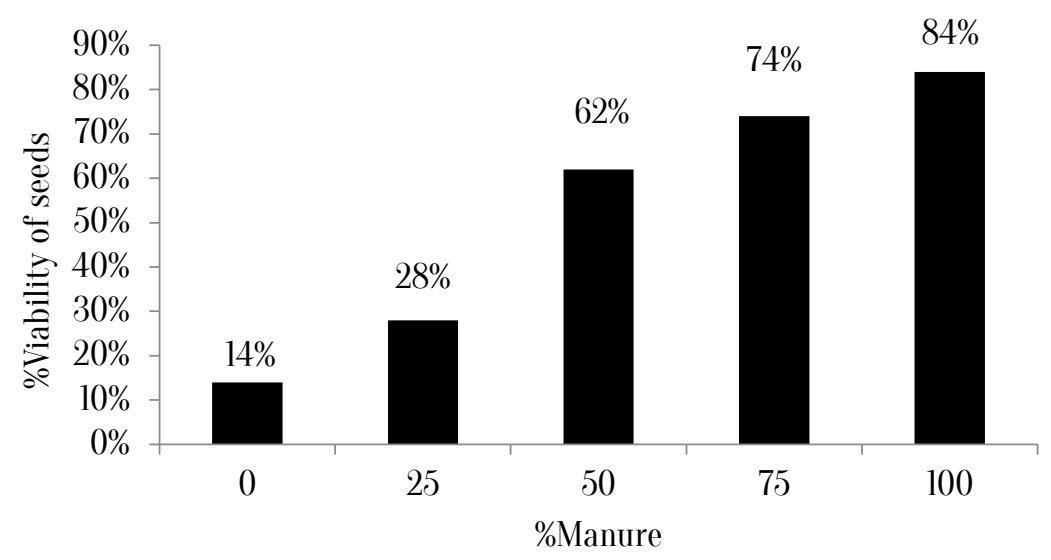

Figure 2. Viability of seeds.

Source: Authors.

Figure 3 shows data about post-emergence abortion of seeds due to such a treatment. The greater post-emergence abortion (34\%) occurred at the treatment 0M-100S; the lower postemergence abortion of seedlings $(0 \%)$, at the treatment $100 \mathrm{M}-0 \mathrm{~S}$; and the average postemergence abortion kept around $6 \%$ to treatments $50 \mathrm{M}-50 \mathrm{~S}$ and $75 \mathrm{M}-25 \mathrm{~S}$.

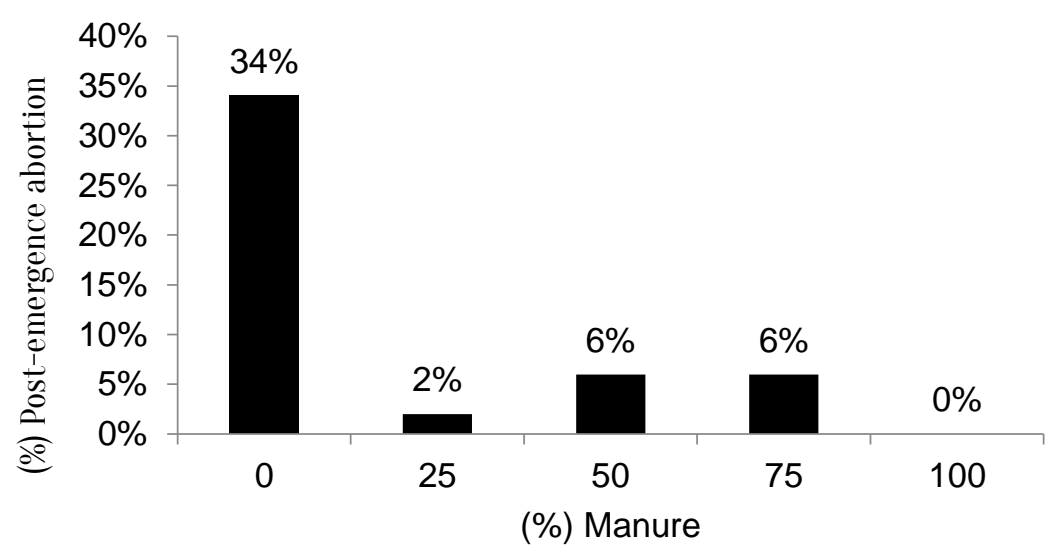

Figure 3. Percentage of abortion of seedlings after germination.

Source: Authors.

Figure 4 shows global germination including aborted seedlings. Considering there was no abortion in the treatment $100 \mathrm{M}-0 \mathrm{~S}$, the higher percentage of germination kept $84 \%$; instead of treatment $0 \mathrm{M}-100 \mathrm{~S}$ with $48 \%$ germination due to the greatest percentage of abortion did not promote the fewer 
percentage of germination; the treatment with minor percentage of germination was $30 \%$ in $25 \mathrm{M}-75 \mathrm{~S}$; and the average germination was $68 \%$ and it occurred in treatment $50 \mathrm{M}-50 \mathrm{~S}$.

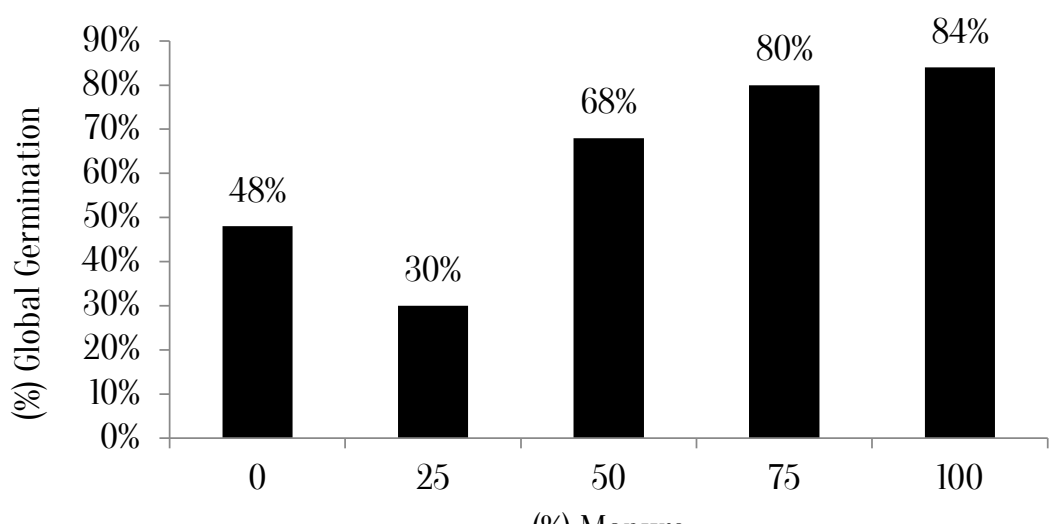

(\%) Manure

Figure 4. Percentage of germination including viable and aborted seedling. Source: Authors.

Table 1 shows the results of $F$ test from Analysis of variance and the variation coefficient of the seedling height, root depth and aerial length characteristics of the seedlings and the average differences in Scott-Knott test to seedling height, root depth and aerial length. About seedling height and root depth the treatments, except $0 \mathrm{M}-100 \mathrm{~S}$, were all statistically equal, with seedling height higher averages between $7 \mathrm{~cm}$ and $8 \mathrm{~cm}$ and root depth higher values around $4.5 \mathrm{~cm}$ and $5.5 \mathrm{~cm}$. About aerial length, $3.45 \mathrm{~cm}$ was the same and higher averages to treatments $100 \mathrm{M}-0 \mathrm{~S}$ and $75 \mathrm{M}-25 \mathrm{~S}$.

Table 1 - Analysis of variance summary in $(\mathrm{cm})$ of the seedling height, root depth and aerial length and Scott-Knott Test

\begin{tabular}{|c|c|c|c|}
\hline \multirow{2}{*}{ Anova } & Seedling height & Root depth & Aerial length \\
\hline & MS & MS & MS \\
\hline Treatment & $5,8931^{* *}$ & $4,0987^{*}$ & 1.4825 \\
\hline Error & 1.32 & 0.85 & 0.25 \\
\hline General average & 7.65 & 4.70 & 2.95 \\
\hline \%VC ～～ & 15.02 & 19.55 & 16.67 \\
\hline Treatments & & Scott-Knott test averag & \\
\hline $100 \mathrm{M}-0 \mathrm{~S}$ & $8.12 \mathrm{a}$ & $4.67 \mathrm{a}$ & $3.45 \mathrm{a}$ \\
\hline $75 \mathrm{M}-25 \mathrm{~S}$ & $8.67 \mathrm{a}$ & $5.23 \mathrm{a}$ & 3.45 a \\
\hline $50 \mathrm{M}-50 \mathrm{~S}$ & $8.38 \mathrm{a}$ & $5.52 \mathrm{a}$ & $2.87 \mathrm{~b}$ \\
\hline $25 \mathrm{M}-75 \mathrm{~S}$ & $7.25 \mathrm{a}$ & $4.58 \mathrm{a}$ & $2.67 \mathrm{~b}$ \\
\hline $0 \mathrm{M}-100 \mathrm{~S}$ & $5.85 \mathrm{~b}$ & $3.53 \mathrm{~b}$ & $2.32 \mathrm{~b}$ \\
\hline
\end{tabular}

F - F-test; MS - mean square; *significant at 5\%; ** significant at 1\%; M - manure; S - sand..

Source: Authors. 
Figure 5 presents the equations to fresh and dry mass and water content according to the doses of manure. The fresh mass presented determination coefficient $\left(\mathrm{R}^{2}\right)$ of 0.9635 ; dry mass, 0.9709 and water content, 0.8954 . The equations show a very similar behavior since the minor dose of manure fresh and dry mass and water content stayed between 0 and $0.05 \mathrm{~g}$; and at the major manure dose fresh mass was $0.22 \mathrm{~g}$ and average $0.19 \mathrm{~g}$, dry mass, $0.06 \mathrm{~g}$ and average $0.06 \mathrm{~g}$ and water content, $0.17 \mathrm{~g}$ and average $0.13 \mathrm{~g}$.

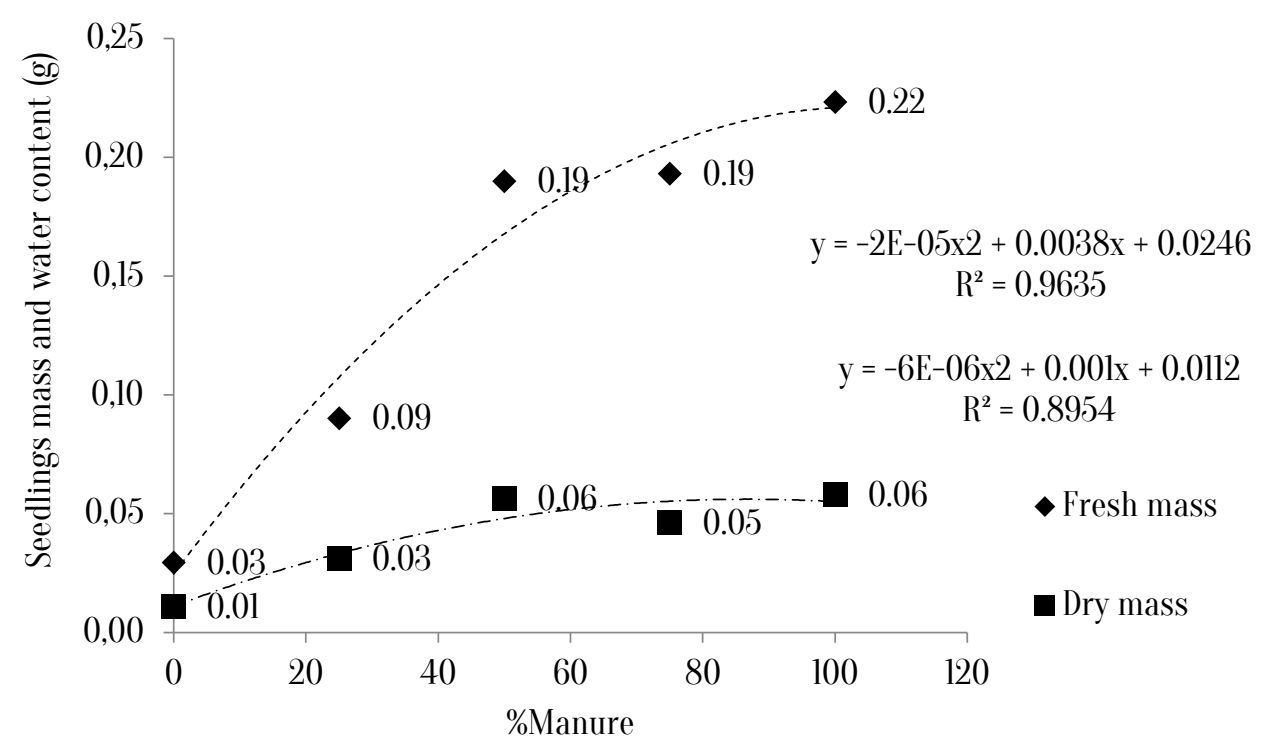

Figure 5. Percentage of abortion of plants after germination. Source: Authors.

About the speed emergence, Costa Filho et al. (2007) found significant differences among the fodder legumes Albizia, Cratília Bean Guandu and Leucaena, only to Albizia, with ESI 0.95; in relation to Cratília ESI was 1.01; Guandú Beans ESI = 2.43 and Leucaena ESI = 1.08. In comparison with substrates ‘sandy soil', 'black soil' and 'vermiculite’ did not differ about ESI.

Working with Capsicum baccatum L. var. pendulum germination and irrigation with treated domestic wastewater and proportions of potable water, Oliveira et al. (2012) found the best germination between $60 \%$ and $65 \%$, respectively, $100 \%$ treated domestic wastewater $+0 \%$ potable water and $75 \%$ treated domestic wastewater $+25 \%$ potable water.

The rate of tomato seed germination was lower when substrate composition rose from $20 \%$ to $40 \%$ in the organic compound content produced in the fermentation yard. But, when the compound was produced directly in the ground there was no difference. The maximum 
germination (97.45\%) occurred when the composition of the substrate, the organic compound content was (10\%) for the compound produced on the ground and a minimum (82.41\%) when the proportion of the compound to the substrate $(40 \%)$ was produced in soil. The compound produced in the fermentation yard, the maximum germination (95.14\%) occurred when the substrate contained $0 \%$-compound and the minimum $(48.84 \%)$ when the proportion of the compound to the substrate was $40 \%$ (Pereira, 2013).

In a study of seed germination of native species of the Cerrado, Mimosa and Aricá, Maas et. al(2011) used various concentrations of commercial substrate, fine vermiculite and biosolids obtained from a sewage treatment station, and it was observed that the higher germination rate, $93 \%$, was achieved by Angico seed in the substrate composed by $100 \%$ of biosolids and the lower, $63 \%$, for the substrate $20 \%$ biosolids $+80 \%$ fine vermiculite; to the species Aricá, the highest germination index was $25 \%$ to the substrate $80 \%$ commercial substrate $+20 \%$ biosolids and lowest was $1 \%$ at $100 \%$ biosolids substrate.

In comparison to studies by Silva et al. (2013), varieties 'Cayene' (ISLA), 'Amarela comprida'(Long Yellow), 'Cheiro de bode 2013' (2013-Goat Smell), 'Dedo de Moça'(Red Pepper) (TECNOSEED), 'Tabasco'(TOP SEED), 'Vulcão 2011' (2011-Vulcano), 'Chapéu de Bispo 2012' (2012Bishop's Hat) presented, respectively, germination rate of $93 \%, 88 \%, 84 \%, 34 \%, 25 \%, 5 \%$ and $0 \%$, 30 days after planting (DAP). Using substrates composed only of land and soil as treatments Charlo et al. (2006) obtained to Archontophoenix alexandrae germination rate of $72.5 \%$ and $75 \%$, respectively. Unlike that obtained for the treatment with treatment 'soil only' of this research, which was obtained merely $10 \%$ of emergence. This may have occurred because of the high density of the substrate (Cambisol) have barred the germination of the pepper seeds.

Oliveira et al. (2012) found the major seedling height at 17 DAS of $6.57 \mathrm{~cm}$ in treatment $100 \%$ treated domestic wastewater $+0 \%$ potable water; and the number of leaves, according to these authors, was 3.6 in treatment $75 \%$ treated domestic sewage wastewater $+25 \%$ potable water.

Dry mass of the eggplant canopy in the treatment earthworm humus and in the treatment coconut fiber + organic compound 1:1 was the same $0.57 \mathrm{~g}$; about dry mass of red pepper in treatment earthworm humus and in treatment organic compound were respectively 0,32g and 0,29g (OLIVEIRA et al. 2006). About root dry mass of eggplant, these authors observed the major mass, $0.33 \mathrm{~g}$, in the treatment coconut fiber + organic compound $1: 1$ and to root dry 
mass of red pepper plant, the higher value in treatment organic compound was $0.117 \mathrm{~g}$. The Best substrates were organic compound and earthworm humus with coconut fiber.

\section{BIBLIOGRAPHICAL REFERENCE}

ARAUJO, T.V.; JOAQUIM, W.M.; BARJA, P.R.. Técnicas de quebra de dormência e estudo de substratos orgânicos para produção de mudas de Leucena. Revista Univap, São José dos Campos, v. 18, n. 32, p.89-100, 2012.

CHARLO, H.C.O.; MÔRO, F.V.; SILVA, V.L.; SILVA, B.M.S.; BIANCO,S.; MÔR0, J.B.. Aspectos morfológicos, germinação e desenvolvimento inicial de plântulas de Archontophoenix alexandrae (F. Mueller) H. Wendl. e Drude (Arecaceae) em diferentes substratos. R. Árvore, Viçosa, v.30, n.6, p.933-940, 2006.

COSTA FILHO, L.C.C.; MELOTTO, A.M.; BOCCHESE, R.A.; LAURA, V.A.; NICODEMO, M.L.F.. Germinação de quatro leguminosas forrageiras lenhosas em diferentes substratos. Revista Brasileira de Biociências. Porto Alegre, v.5, n.2, p.366-368, 2007.

MAAS, K.D.B.; ARRUDA, C.A.S.; RONDON NETO, R.M.; MORAIS, M.A.V.; GUIMARÃES, M.L.F.. Biossólido na germinação de espécies nativas do cerrado. In: Seminário Nacional de Resíduos Sólidos: por uma gestão integrada e sustentável, 9., Palmas, 2011.

MAGUIRE, J.D.. Speed of germination-aid in selection and evaluation for seedlig emergence and vigor. Crop Science, Madison, v.2, n.1, p.176-178, 1962

OLIVEIRA, J. F.; ALVES, S. M. C.; FERREIRA NET0, M.; OLIVEIRA, R. B.. Efeito de água residuária de esgoto doméstico tratado na produção de mudas de pimenta Cambuci e quiabo. Enciclopédia Biosfera, Goiânia, v.8, n.14, p.443-452, 2012.

OLIVEIRA, J. P. B.; LOPES, J. C.; ALEXANDRE, R. S.; JASPER, A. P. S.; SANTOS, L. N. S.; OLIVEIRA, L. B.. Efeito do lodo de esgoto no desenvolvimento inicial de duas cultivares de mamona em dois tipos de solos. Engenharia Ambiental, Espírito Santo do Pinhal, v.6, n.2, p. 174-180, 2009.

OLIVEIRA, M. K. T.; OLIVEIRA, F. A.; MEDEIROS, J. F.; LIMA, C. J. G. S.; GALVÃ0, D. C.. Avaliação de substratos orgânicos na produção de mudas de berinjela e pimenta. Revista Verde, Mossoró, v.l, n.2, p.24-32, 2006.

PEREIRA, R.A.. Compostagem em pequena escala e uso do composto como substrato na germinação de sementes de tomate (Lycopersicum esculentum). 2013. Dissertação (Mestrado em Sistemas Agroindustriais) - Universidade Federal de Campina Grande, Pombal.

PEREIRA, F.E.C.B.; TORRES, S.B.;SILVA, M.I.L., GRANGEIRO, L.C.; BENEDITO, C.P.. Qualidade fisiológica de sementes de pimenta em função da idade e do tempo de repouso pós-colheita dos frutos. Revista Ciência Agronômica, Fortaleza, v.45, n.4, p.737-744, 2014.

SILVA, R.R.; FREITAS, G.A.; SIEBENEICHLER, S.C.; MATA, J.F.; CHAGAS, J.R.. Desenvolvimento inicial de Theobroma grandiflorum (Willd. Ex Spreng.) Schum. sob influência de sombreamento. Acta Amazônica, Manaus, v.37, n.2, p.365-370, 2007.

SILVA, B.R.; SCHARMOSIM, S.E.; SELAU, D.E.; CANDIA, A.S.F.; SEIBERT, E.. Avaliação da germinação e do desenvolvimento das mudas de diferentes variedades de pimentas. In: Simpósio de Integração Científica e Tecnológica do Sul Catarinense SICT-Sul, 2., Araranguá, 2013.

WAGNER JUNIOR, A.; ALEXANDRE, R.S.; NEGREIROS, J. R. S.; PIMENTELL. D.; SILVA, J. O. C.; BRUCKNER, C.H.. Influência do substrato na germinação e desenvolvimento inicial de plantas de maracujazeiro amarelo (Passiflora edulis Sims f. flavicarpa Deg). Ciência Agrotécnica, Lavras, v.30, n.4, p.643-647, 2006. 